\title{
THE ROLE OF RELATIVE SLOPE LENGTH IN FLOOD HAZARD MAPPING USING AHP AND GIS (CASE STUDY: LAM RIVER BASIN, VIETNAM)
}

\author{
Nguyen Ba Dung ${ }^{1 *}$, Dang Tuyet Minh ${ }^{2}$, Adeel Ahmad ${ }^{3}$, Nguyen Quoc Long ${ }^{4}$ \\ ${ }^{1}$ Hanoi University of Natural Resources and Environment, Hanoi, Vietnam \\ 2Thuyloi University, Vietnam, Hanoi, Vietnam \\ ${ }^{3}$ Department of Geography, University of the Punjab, Lahore, Pakistan \\ ${ }^{4}$ Hanoi University of Mining and Geology, Hanoi, Vietnam \\ *Corresponding author: nbdung@hunre.edu.vn \\ Received: March 4" ${ }^{\text {th }}, 2020$ / Accepted: May 10 ${ }^{\text {th }}, 2020$ / Published: July 1'st 2020 \\ https://DOI-10.24057/2071-9388-2020-48
}

\begin{abstract}
In addition to the five main factors affecting the formation of floods including slope, rainfall, drainage density, soil, and land cover, the relative slope length factor has also been considered to be one of the fundamental causes that contribute to flood hazard. The paper analyzes the theoretical basis for choosing the relative slope length criterion when zoning flood hazard in Lam river basin. The important role of this factor was evaluated by the results of the flood risk zoning map established by the method of integrating AHP and GIS technology in two cases: using 5 flood influence criteria and using 6 flood influence criteria. Flood hazard zoning maps for 2 cases were tested with 3 historic floods occurring on Oct 2010, Oct 2013 and Oct 2016. The results showed that the map established with six influence factors is more detailed and accurate than the one created with five factors affecting flood hazard because of the similarity with the reality of that map. The results of the study are applicable to other river basins which their geographical features are similar to characteristics the Lam river basin.
\end{abstract}

KEY WORDS: Relative slope length, slope length, flood hazard zoning, AHP algorithm, Lam river basin

CITATION: Nguyen Ba Dung, Dang Tuyet Minh, Adeel Ahmad, Nguyen Quoc Long (2020). The Role Of Relative Slope Length In Flood Hazard Mapping Using Ahp And Gis (Case Study: Lam River Basin, Vietnam). Geography, Environment, Sustainability, Vol.13, No 2, p. 115-123

https://DOl-10.24057/2071-9388-2020-48

Conflict of interests: The authors reported no potential conflict of interest.

\section{INTRODUCTION}

Floods are among the most common and most destructive natural disasters in Vietnam causing serious consequences (El Alfy 2016; Chau et al. 2013), threatening people's lives and slowing down the progress of socio-economic development. In period 1989 to 2014, floods caused considerable losses including at least 14,867 dead and missing people, asset damages equivalent to $1 \%$ of GDP for Vietnam (Chinh et al. 2018) and especially in agriculture, the extreme flood can affect more than $40 \%$ of wet rice production (Chau 2013). Floods also bring sediments with it (Bastawesy et al. 2009) and more sedimentation can result in clogging of drainage systems (El Alfy 2016). Widespread flooding with dramatic damages has shown the importance of flood mitigation and disaster response. In order to solve this problem, the first important mission is that building the flood hazardzoning map, one of the powerful tools to identify flood-prone zones. The production of flood hazard maps is an important component of flood risk assessment and management activities (Chau et al. 2013; Luu et al. 2018).

There are many methods to establish the flood hazard zoning map such as the Hydrological method, Analytic Hierarchy Process (AHP) method, Statistic method, etc., but the AHP method is one of the most effective procedures because of its easy usage and high flexibility (Minh 2017a). In Vietnam, this approach has appeared in the early years of the previous decade with some typical studies in Vu Gia - Thu Bon river (Tu et al. 2013), Hương river (Phương et al. 2015), Lam basin river (Minh and Dung 2017), river system in Quang Nam province (Chinh et al. 2018; Luu et al. 2018). AHP is a mathematical model for assigning the weight and rank to each factor used in the multi-criteria decisionmaking process (Souissi et al. 2019). When developing a flood risk zoning map using the Analytical Hierarchy Process (AHP) method, the selection of the factors leading to the formation of floods will determine the accuracy of the research results. Using AHP technique, the criteria that have a significant influence on flood formation in the river basins and other geographical areas have been published by many scientists in research of the different geographical areas including rainfall, slope, soil, land use, drainage density, land cover, irrigation system, etc. (Radwan et al. 2019; Seejata et al. 2018; Vojtek and Vojteková 2019). In fact, there are many various factors affecting flood generation such as physical geography, socio-economic, infrastructure factors (Elkhrachy 2015; Kazakis et al. 2015; Rahmati et al. 2016). According to (Tran et al. 2008), the flood is not a pure risk disaster but this phenomenon has deep roots in social vulnerabilities and inappropriate environment management. For each geographical area, the criteria as well as the level of impact on the flood are also different and there are no specific factors for flood susceptibility (Rahmati et al. 2016). 
In the Lam river basin, apart from the aforementioned factors, the slope length factor is also one of the main causes affecting the flood risk. Slope length is defined as the distance from the point of origin of overland flow to the point where the slope decreases to the extent that deposition begins or to the point where runoff enters a defined channel (Zhang et al. 2017). This factor is known as one of the key factors that impact the flow volume (Yongmei et al. 2011) and runoff velocities (Gilley et al. 1987). The slope length has been studied a lot when assessing its effect on erosion. The effect of slope length on erosion occurs through an increase in the volume and the speed of runoff, resulting in increased capacity of the runoff to disaggregate and transport sediments (Bagarello and Ferro 2010). The research of (Bagio et al. 2017) revealed that the increase in erosion with the length of the slope is explained by the greater erosive power of surface runoff, determined mainly by the increase in the volume and speed of runoff (Bagio et al. 2017). Therefore, the longer the slope length, the higher the flow velocity and the greater the runoff volume. This leads to the slope length also significantly affecting the flood formation. There are two kinds of slope length: absolute and relative slope length. However, it is not easy to implement the absolute length hierarchy of all slopes in the study area by AHP, so the latter one will be mentioned in this study. The objective of the current study is to analyze the importance of relative slope length factor in making a flood hazard zonation maps using AHP associated with GIS techniques.

\section{RESEARCH AREA}

The Lam river system is located within $103^{\circ} 14^{\prime}$ to $106^{\circ} 10^{\prime} \mathrm{E}$ and $17^{\circ} 50^{\prime}$ to $20^{\circ} 50^{\prime} \mathrm{N}$, lasts approximately $350 \mathrm{~km}$ in the NWSE direction (Fig. 1). In Vietnam, more than $80 \%$ of the area is mountainous (Kieu 2011). The topography of the Lam river basin is complex distribution, the upstream and middle areas are steep terrain, while the terrain of downstream areas is quite flat. The terrain of the river basin is like a sloping roof that the peak is the Truong Son mountain range in the west and descending to the east. This makes it easy to concentrate the flow downstream quickly to create large floods. The average annual rainfall in the Lam river basin in the period 1961-2017 measured at Muong Xen station is 1,039,883 $\mathrm{mm}$ (lowest) and at the Ky Anh station is 2,899,900 mm (highest) (Kieu 2011).

As one of the nine major river systems of Vietnam, the Lam River system has two major tributaries, the Ca river and the La River. The drainage density of the Lam river basin is approximately equal to that of the central rivers $\left(0.67 \mathrm{~km} / \mathrm{km}^{2}\right)$. The soil in the mountainous area of the Lam river basin is quite good, the thickness of the soil layer is more than $50 \mathrm{~cm}$, the good soil structure consists of 38 different soils which are unevenly distributed throughout the basin and can be divided into the main land groups including alluvial soil, red yellow feralit soils, coastal sand groups, and mangrove groups. The Lam river basin is rich in land cover including broadleaf evergreen forest, renew forest, mixed bamboo forest, residential land, shrubs, agricultural land, bare lands, cultivated aquatic land, other lands. Currently, the area of vacant land, bare hills on the Lam River basin is quite high, about 20\% of natural land area (Kieu 2011).

Thus, with such natural conditions, the factors which can cause flooding in the Lam river basin including heavy rainfall on large areas, rich soils, thick drainage density, steep slope, land use for many purposes. These are the most important factors for the formation of the floods when heavy rainfall occurs for long periods. However, the watershed line of the southern and southwestern regions of the Lam river basin passes through mountains with an average elevation of 1,300-1,800 m. Also, the average slope of the sub-basins of the research area varies from $1 \%$ to $40 \%$, so the slope length will be relatively great leading to higher risks of flooding. In the mountainous areas, the slope is different, the value of slope length is different, that means flood hazard also different. Therefore, it is necessary to consider the slope length element or the distance from the watershed line to the location where assessing the flood hazard (Minh 2019b).

\section{DATA AND METHODS}

\section{Analyzing the effects of slope length on flood hazard The concept of slope length}

Slope length is the distance from the origin of overland flow along its flow path to the location of concentrated flow or deposition. According to (Widchmeier and Smith 1978), slope length has been defined as «the distance from the starting point of overland runoff (the top of the hillslope) to one of two following locations: (a) the point where the slope decreases sufficiently for deposition to occur, (b) the position where flow concentrates a clearly-defined channel (wet or dry) that may be a part of a drainage network or a constructed channel such as a terrace or diversion» (Wischmeier and Smith 1978). Thus, this length is equal to the distance calculated from the watershed line

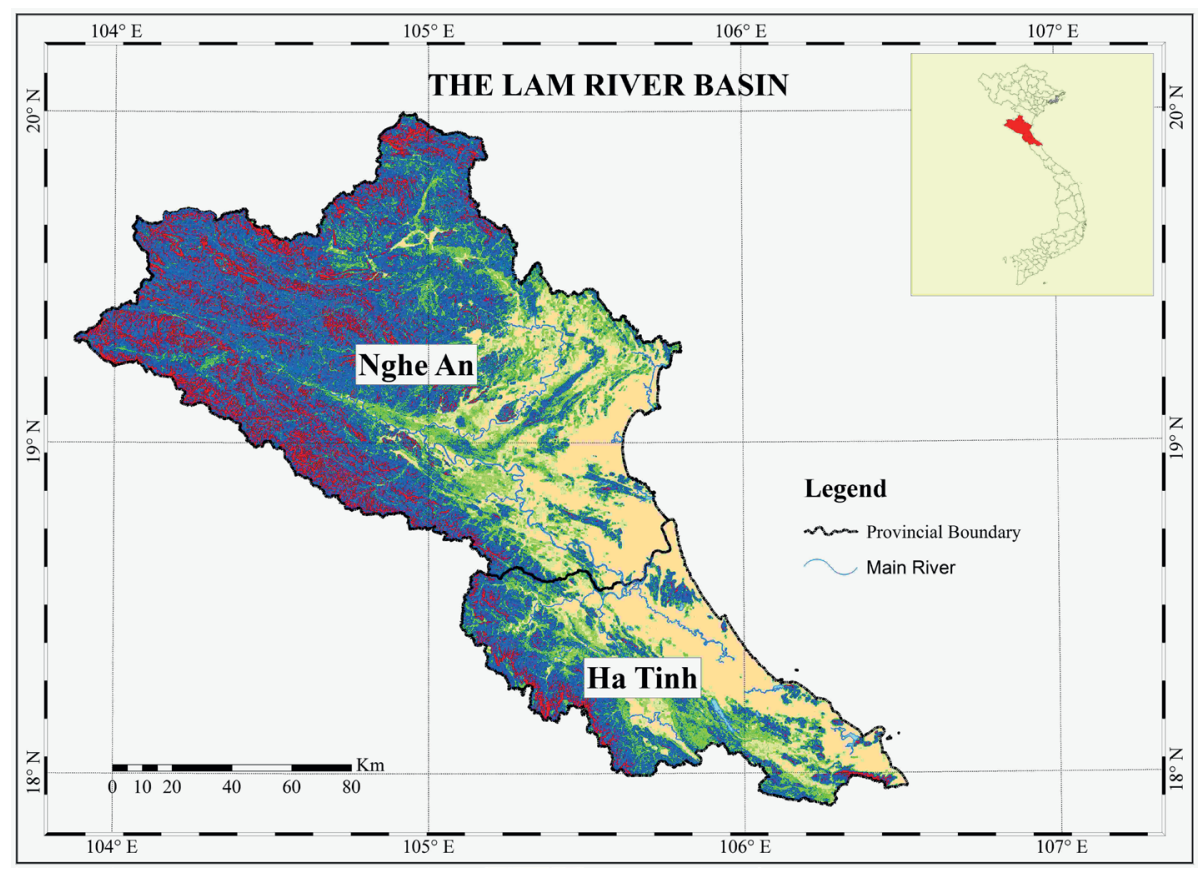

Fig. 1. The Lam river basin 
to the valley line. A watershed is an area of land that drains to a stream, river, lake or ocean. It is a land surface feature that can be identified by connecting the highest elevations between two areas. During rainstorms, some water runs off both parts of the watershed but meets in the valley, stream, river, etc.

When measuring in units of distance, it is the absolute slope length. In some cases, for example, according to National Standards TCVN 5299: 2009, the erosion calculation caused by rain, slope length can be segmented by distance from the top of the slope to the base of the slope (Ministry of Science and Technology 2009), then the slope length is a relative slope length. In fact, there will be two concepts existed: the relative slope length and the absolute slope length. The relative slope length is the length of a segment relative to the entire slope length. The absolute slope length is normally measured in length measurement units, meaning "absolute" in terms of quantitative while the relative slope length is hierarchized based on the percentage of absolute slope length, so it means "relative" in terms of quantitative. The absolute slope length will be more meaningful in calculating the hydrological, hydraulic models but it is difficult in the hierarchy to determine the weight for the AHP model (Minh 2019b). Therefore, this paper uses a relative slope length.

\section{The theoretical basis for choosing the relative slope length factor in zoning flood hazard}

In reality, because water accumulates gradually in the process of moving along the slope from high to low and flood usually only occurs in the lower area, so the slope length is a factor that affects both floods as well as the possibility of flooding. According to Begarello and Ferro, an increase in slope length will increase flow volume and flow speed as well (Bagarello and Ferro 2010; Kinnell 2004). The longer the slope length, the greater the volume of water, flow speed, and inertia force. That is, the further the distance from the watershed line, the greater the kinetic energy of the flow, the higher the velocity of the flow leading to an increase in flood risk. Moreover, when the slope length increases, the tilted area will increase as well, hence the further the distance from the watershed line is, the more the volume of water accumulated on the surface will be. This conclusion is also consistent with the research of (Yongmei et al. 2011). In the research, the authors conducted an experiment to observe rain-flow in areas with different slope lengths, and the results have shown that the flow volume increases with an increasing slope length (Yongmei et al. 2011). With the same results, (Liu \& Singh 2004) studied runoff generation for four types of slope lengths. The modeling showed that the unit discharge increased remarkably as the slope length increased. The longer the slope was, the larger the unit discharge was (Liu \& Singh 2004).

Thus, on the same slope, the volume of water, flow velocity as well as the ability to accumulate water will increase gradually as the water flows from the watershed line to the valley line. Moreover, the capacity of water accumulation on the slope is dependent on the time of water concentration. The time of rainwater concentration on the slope depends on the hydrogeological coefficient of the slope (\$sd) and the rain zone (Fig. 2) calculated by the formula (Directorate for Roads of Vietnam 2013): in which

$$
\phi_{s d}=\frac{L_{s d}^{0.6}}{m_{s d} J_{s d}^{0.3}\left(\varphi H_{p}\right)^{0.4}}
$$

$\mathrm{L}_{\mathrm{sd}}$ : Average slope length of the basin $(\mathrm{m})$

$\mathrm{J}$ : Slope in \%

$\varphi$ : Flood flow coefficient depending on the soil type, design daily rainfall and basin area.

$H_{p}$ : design daily rainfall

$\mathrm{m}_{\mathrm{sd}}$ : Parameter of roughness characteristics on the slope, depending on the surface condition of the basin slope

According to (Directorate for Roads of Vietnam 2013), the time of water concentration on the slope increases when the geomorphology and hydrological coefficient of the slope increases. The relevance between these two values is expressed in a line chart, where $X$-axis uses for $\Phi_{\text {sd }}$ Y-axis for the time of water concentration, and separate lines represent rain zones as Fig. 2. Also, formula (1) shows that coefficient $\Phi_{\text {sd }}$ is proportional to the slope length. This proves that the greater the slope length, the more the time of water concentration and the greater the flood risk. Thus, the slope length is also one of the main causes of flooding.

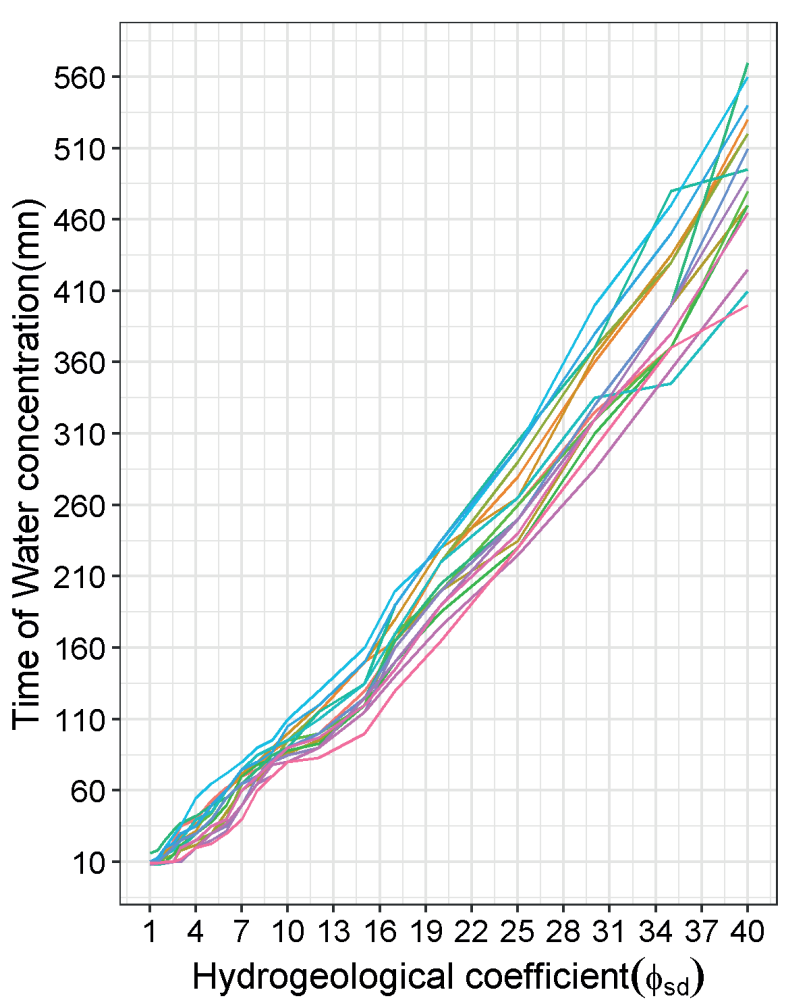

Rain_Zone

- I

- $॥$

- III

- IV

$-\mathrm{IX}$

$-\mathrm{V}$

$-\mathrm{Vl}$

- VII

- VIII

$-x$

$-x \mid$

$-\mathrm{XII}$

$-X I I I$

- XIV

$-X V$

$-X V I$

$-X V I I$

- XVIII

Fig. 2. The time of water concentration on the slope based on the hydrogeological coefficient of the slope and the rainy areas 


\section{DATA SETS AND METHODOLOGY \\ Data Sets}

There are many indicators affecting flood hazard, and they vary from one study area to another. This paper used a composite flood hazard map index based on six variablescriteria, the flood causative factors, namely, the rainfall, the slope, the soil, the land cover, the drainage density, and the relative slope length. The selection of these elements was actually based on their relevance to flood occurrences as well as physical conditions of the study area. The study used various sources of documents including the topographic map, current land use map, administrative boundary map, map of river and stream system of Lam river basin, location map of hydrological stations in Lam river basin in scale 1:50,000 and the average rainfall data at some locations on Lam river basin in the period 1961 to 2017. These data obtained from concerned government agencies such as Vietnam National Space Center, Department of Natural Resources and Environment of Ha Tinh, Nghe An, and Thanh Hoa provinces and National Centre for Hydrometeorological Forecasting.

\section{METHODOLOGY}

Based on digitized topographic maps (20 m interval) in scale 1:50,000 and the geo-referenced in the National coordinating system, the digital elevation model (DEM of $30 \mathrm{~m}$ grid cell resolution) was derived. The slope map and relative slope length map will be created from this DEM. Also based on the DEM and map of river and stream system of Lam river basin, the subbasins boundaries were also determined and several calculations were finally made as far as the flow direction and accumulation, the main flow length of each river tributary, the subbasin area and the drainage density index. From that, the drainage density map is built. Furthermore, average annual rainfall dataset for a large time period (19612017) from 20 meteorological stations covering the regional area was obtained from the National Centre for HydroMeteorological Forecasting (NCHMF). This kind of data helped to make the rainfall distribution map for the study area. In addition, through the current land use map (2015), the study area's land cover was identified and categorized according to flood susceptibility. Simultaneously, this map is used to establish a soil map. Taking into account the soil map within the Lam river bansin, each soil type was assorted and ranked according to its texture, penetration, and vulnerability to flood event. Each criterion was spatially visualized in a thematic map after processing in a GIS environment and was classified into five classes: Very Low; Low; Moderate; High and Very High by the Arcmap version 10.2 (Link: http://desktop.arcgis.com/en/ arcmap/).

The evaluation of the accuracy of the map factors affecting the flood is done by comparing the result with the actual ones. The drainage density map is verified by alarm level and corresponding risk level at 5 hydrological stations in the Lam river basin with three historical flood events: October 16-18, 2010; October 15-16, 2013; and October 15-16, 2016. The verification results show that there is a similarity between the map of land cover (Minh 2017b), soil (Minh 2017c), drainage density (Minh 2019a), relative slope length (Minh 2019b) and risk level at hydrological stations: Hoa Duyet, Linh Cam, Nam Dan, Chu Le, and Do Luong. For the slope map and the rainfall map, besides comparing these maps to the actual situations, these products are examined by making a comparison with the same type of maps establishing by other methods in research of Kieu (2015). Therefore, it is reasonable to infer that the results are almost consistent with reality and previous research.

In this paper, the authors have adopted an AHP method associated with GIS environment to manipulate the physical factors in the production of flood hazard zoning map. Fig. 3 presents a flowchart of the methodology applied in this research. Being a systematic approach developed in the 1970s, the AHP method gives decision-making based on experience, perception, and heuristics acquired from logical mathematical principles (Bhushan and Rai 2004) and help in organizing the complex problem in a simple way to follow and analyze. This algorithm aims in detecting the flood risk areas in the study region by recognizing the most flood-affected parameters based on the decision-makers' preferences being capable of altering subjective assessments of importance into a set of weights, (Kandilioti et al. 2012; Myronidis et al. 2009; Stefanidis et al. 2013). In otherwords, personal evaluations are transformed into numerical values and handled to rank each alternative in this study on a numerical scale. In the AHP implementation, a pairwise comparison technique is used to derive the priorities for the criteria in terms of their importance in achieving the goal. In this study, there there are 6 factors that contribute to flood formation, so the number of comparisons will be $6^{*}(6-$ 1)/2. The score of pairwise comparison of these criteria will

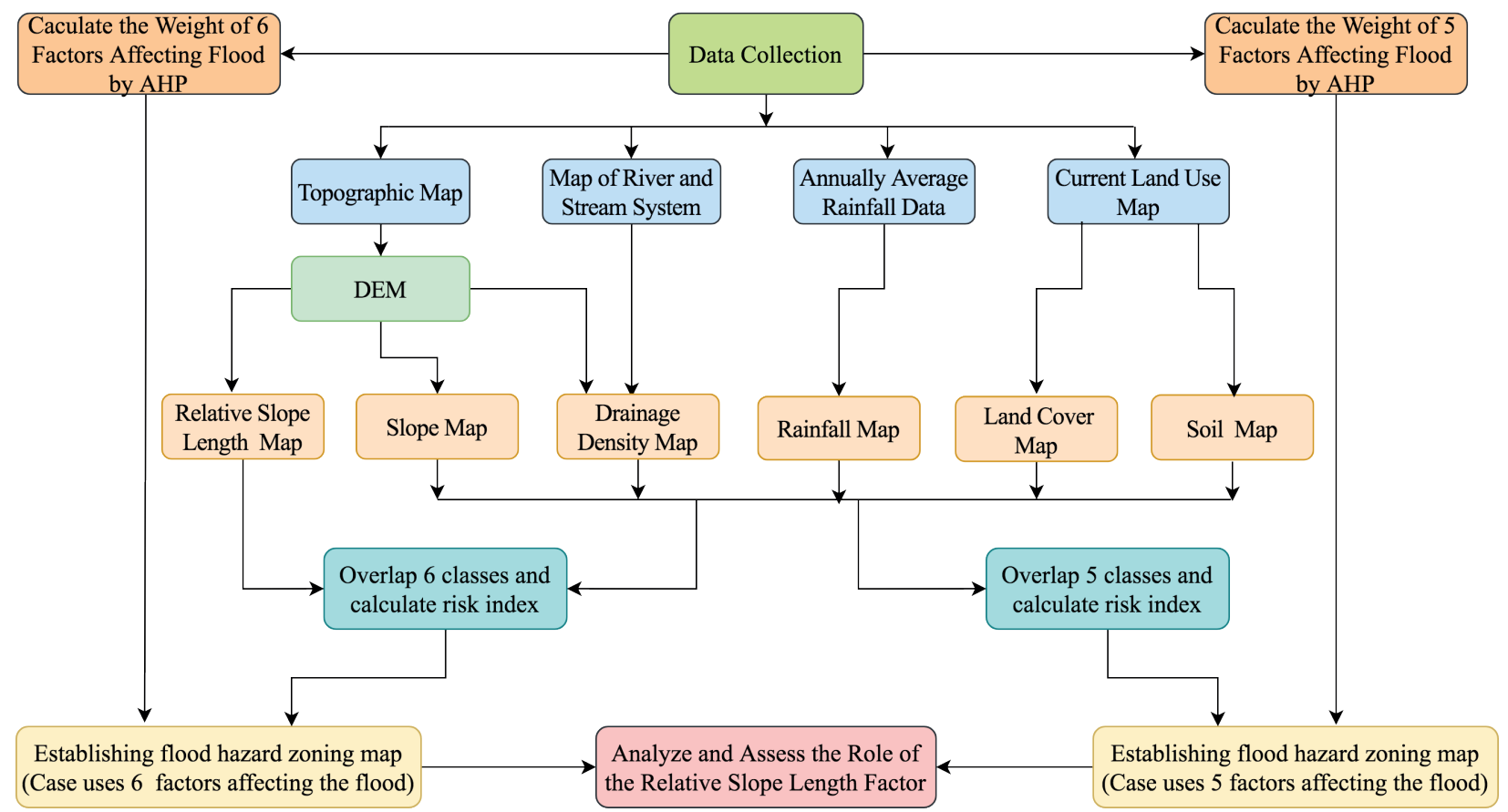

Fig. 3. Methodology flowchart 
be the coefficient of the pairwise comparison matrix. The relative significance between the factors is assessed along the row from 1 to 9 pinpointing less important to much more important criteria, respectively whereas the corresponding column assigns the reciprocal of the weight (from $1 / 2$ to 1/9) (Lappas and Kallioras 2019). The weight of the parameters can be computed using two methods: eigenvector method and normalization matrix method. The priority vector shows relative weights among the things that we compare. In this paper, the second method is employed to obtain the weight of the factors. A higher weight value of the factors represents more priority or more impact than others within the study. That means, the greater the weight of a factor becomes, the more that factor influences the flood hazard. However, there are existed errors in pairwise comparison and this leads errors in evaluation. To check and eliminate errors as well as examine the importance of the factors, according to (Saaty 2012), using consistency ratio (CR) of data. A Consistency Ratio (CR) indicates the probability that the matrix ratings were randomly generated and when CR is less than or equal to the threshold 0.1 signifies an acceptable reciprocal matrix, while ratio over 0.1 implies that the matrix should be revised indicating inconsistent judgments.

Once the weights for the factors are determined, a multicriteria evaluation is performed by utilizing the specific weights and the maps for six factors to create the flood hazard zoning map. The basis of flood risk zoning will be generalized into the equation for calculating the risk score according to the hierarchy score of six factors:

$$
H I=\sum_{1=1}^{6} w_{i} * X_{i}
$$

in which

HI: Hazard Index (risk score)

$X$ : Hierarchy score of factor $\mathrm{i}(\mathrm{i}=1-\mathrm{n})$

$w_{i}$ : The weight of factor i

\section{RESULTS AND DISCUSSION}

The research carries out in 2 cases. The first case uses 5 factors affecting the flood hazard to calculate the weights and makes a flood hazard zoning map including rainfall, slope, soil, land cover, drainage density. The remaining alternative, using five elements of the above plan and adding a relative slope length criterion to calculate a model and generate a flood hazard zoning map. Table 1 shows the weight of the criteria calculated according to the AHP method in 2 cases (Minh 2019b; Dung et al. 2020).

Based on the weight of factors calculated as Table 1, combined with the map of the influence criteria, the flood hazard zoning map of the river Lam basin is created by the spatial analysis method in the GIS environment. With the different numbers of influence parameters, flood risk zoning results are also different. It can be seen the difference between the results of flood risk zoning in two cases: five influence factors (Fig. 4) and six influence factors (Fig. 5).

Obviously, the results of the flood hazard zoning map using six influence factors are more detailed and specific than the remaining case. While this map indicates high-risk areas that are concentrated mainly in the districts of Huong Khe, Huong Son, Duc Tho, Can Loc, Thach Ha, Vu Quang, and Hung Nguyen, the results of the flood hazard zoning using five influence factors do not highlight this high-risk area.

Table 1. The weight of influencing factors

\begin{tabular}{|c|c|c|}
\hline Criteria & Weight (case of 5 factors affecting flood) & Weight (case of 6 factors affecting flood) \\
\hline Rainfall & 0.495 & 0.45 \\
\hline Slope & 0.276 & 0.255 \\
\hline Drainage desity & 0.082 & 0.077 \\
\hline Soil & 0.071 & 0.068 \\
\hline Land cover & 0.077 & 0.073 \\
\hline Relative slope length & & 0.077 \\
\hline
\end{tabular}

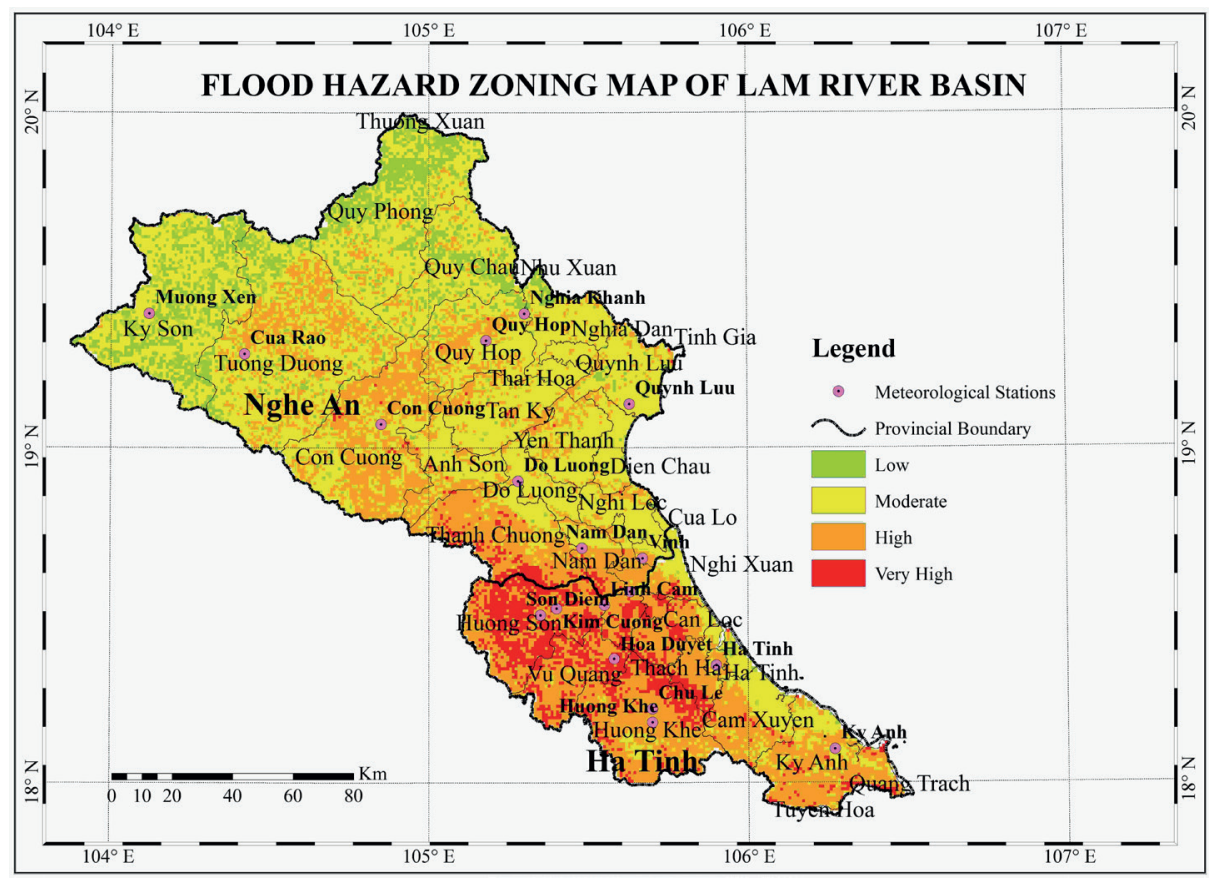

Fig. 4. Flood hazard zoning map of Lam river basin ( using 5 influence factors) 
The research results can be verified based on the flood alarm level at the hydrological stations on the river of the study area (Do Luong, Son Diem, Hoa Duyet, Linh Cam and Nam Dan) with three typical flood events including October 16-18, 2010; October 15-16, 2013; and October 15-16, 2016. Three levels of flood alarms can assess corresponding to the hazard level in the study as follows: Above alarm 3 - the risk of flooding is very high; Above alarm 2 - high flood risk; Above alarm 1- average flood risk; Under alarm 1- low flood risk.

According to decision No. 05/2020/QD-TTg signed on January 31, 2020 of the prime minister, the water levels corresponding to the flood alarm levels on the Do Luong, Nam Dan, Son Diem, Hoa Duyet, Linh Cam, Chu Le hydrological stations on the rivers of the river Lam basin are shown on Table 2. Compare the water levels of the hydrological stations in the historical floods to flood alarm levels in corresponding stations (Table 2), this indicates the relevance of the research results with the historical floods in reality.

Tables (from 3 to 5) show flood alarm levels and respective hazard levels at hydrological stations during the three floods. The similarities of the research results and the reality can be compared based on risk levels on the hazard zoning map for 2 cases (using 5 factors and using 6 factors affecting flood fomation). The comparison result shows the level of conformity between alarm levels on some hydrographic stations and the results of the flood hazard zoning of the study in the three flood events as follows:

The above test results show that there is very little mismatch on the map using 5 criteria affecting flood hazard, while most of the areas with very high flood risk in the flood risk zoning map using 6 influence factors are similar to reality. This is clearly shown in columns 7 and 9 in Table 3, 4, and 5. In particular, the Chu Le area is always at very high flood risk and suitable for over alarm level 3 of many floods. According to the survey data of Ha Tinh Committee for Flood and Storm Control, in addition to 3 flood events mentioned above, alarm level at the Chu Le station of most historical floods is over alarm level 3. For example, a flood of September 29 - October 2, 2009 (over alarm 3, 3.06 m); a flood of October 4, 2010 (over alarm 3, 1.52 m); a flood of September 26, 2013 (over alarm 3, 0.3 m); a flood of October 29 - November 4, 2016 (over alarm 3, 0.21 m);

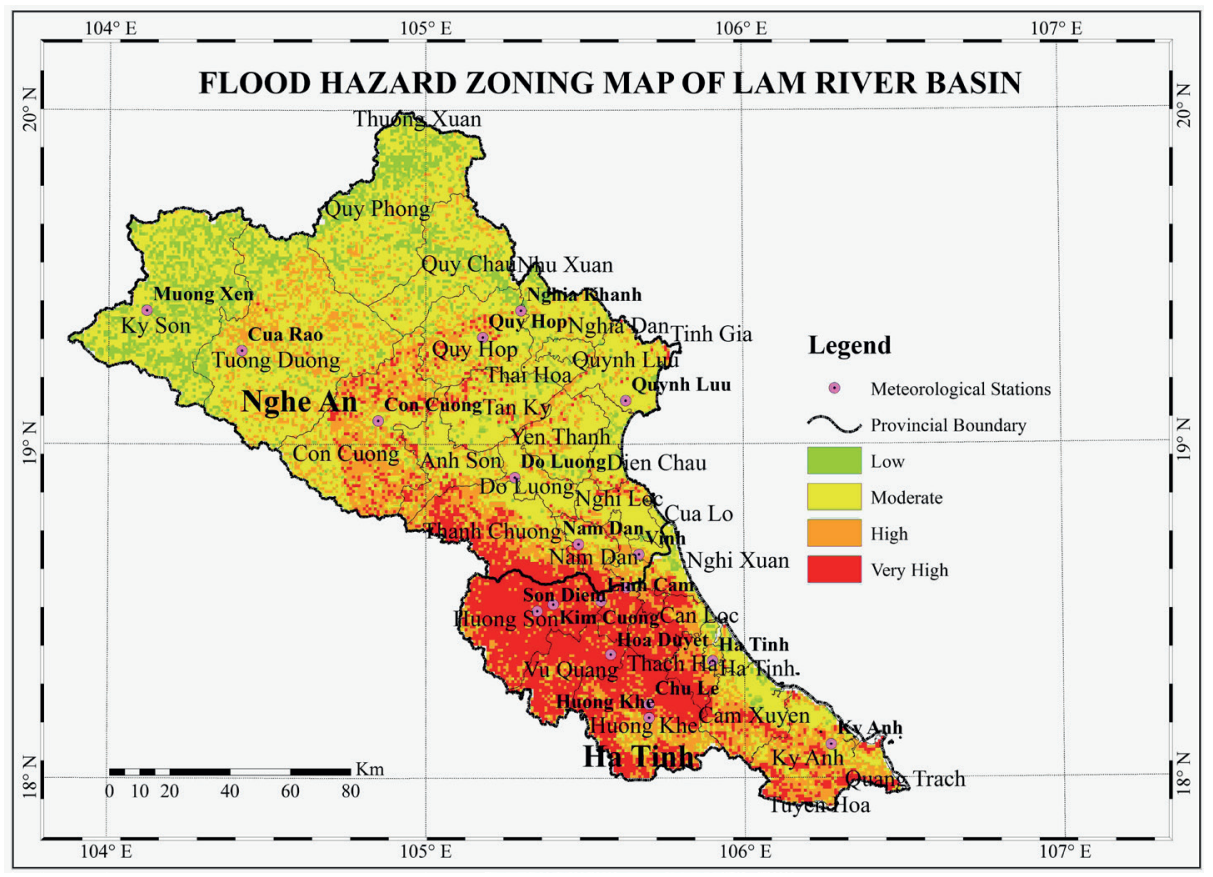

Fig. 5. Flood hazard zoning map of Lam river basin ( using 6 influence factors)

Table 2. The water levels corresponding to the flood alarm levels on the rivers of the river Lam basin

\begin{tabular}{|c|c|c|c|c|c|c|}
\hline \multirow{2}{*}{ No. } & \multirow{2}{*}{ Province } & \multirow{2}{*}{ River } & \multirow{2}{*}{ Hydrological stations } & \multicolumn{3}{|c|}{ Water level corresponds to the alarm level (m) } \\
\hline & & & & I & $\|$ & III \\
\hline 1 & \multirow{2}{*}{ Nghe An } & \multirow{2}{*}{$\mathrm{Ca}$} & Nam Dan & 5.4 & 6.9 & 7.9 \\
\hline 2 & & & Do Luong & 14.5 & 16.5 & 18.0 \\
\hline 3 & \multirow{4}{*}{ HaTinh } & La & Linh Cam & 4.5 & 5.5 & 6.5 \\
\hline 4 & & Ngan Pho & Son Diem & 10.0 & 11.5 & 13.0 \\
\hline 5 & & \multirow{2}{*}{ Ngan Sau } & Hoa Duyet & 7.5 & 9.0 & 10.5 \\
\hline 6 & & & Chu Le & 11.5 & 12.5 & 14.0 \\
\hline
\end{tabular}

(Sources: Decision No. 05/2020/QD-TTg of Prime Minister's: Regulation of water levels corresponding to the flood alarm levels on nationwide rivers)

* With the flood on October 16-18, 2010

- The flood hazard zoning map using six influence factors: Flood risk level in this map is suitable to the actual risk level at 5/5 hydrological stations.

- The flood hazard zoning map using five influence factors: Flood risk level in this map is only suitable to the actual risk level at Son Diem hydrological station. 
Table 3. Water level, Alarm level and hazard level at Hydrological stations in flood event October 16-18, 2010

\begin{tabular}{|c|c|c|c|c|c|c|c|c|}
\hline No. & $\begin{array}{c}\text { Hydro-logical } \\
\text { Stations }\end{array}$ & $\begin{array}{c}\text { Water level } \\
(\mathrm{m})\end{array}$ & Alarm level & $\begin{array}{c}\text { Hazard level in } \\
\text { reality }\end{array}$ & $\begin{array}{c}\text { Risk level on a } \\
\text { map using } \\
6 \text { factors }\end{array}$ & $\begin{array}{c}\text { Comparison } \\
\text { Results }\end{array}$ & $\begin{array}{c}\text { Risk level on a } \\
\text { map using } \\
5 \text { factors }\end{array}$ & $\begin{array}{c}\text { Comparison } \\
\text { Results }\end{array}$ \\
\hline 1 & Son Diem & 13.00 & $\begin{array}{c}\text { Over alarm level } 3 \\
(0,78 \mathrm{~m})\end{array}$ & Very high & Very high & Similarity & Very high & Similarity \\
\hline 2 & Hoa Duyet & 12.37 & $\begin{array}{r}\text { Over alarm level 3 } \\
(1,87 \mathrm{~m})\end{array}$ & Very high & Very high & Similarity & High & No Similarity \\
\hline 3 & Linh Cam & 7.28 & $\begin{array}{r}\text { Over alarm level 3 } \\
(0,78 \mathrm{~m})\end{array}$ & Very high & Very high & Similarity & Ho Similarity \\
\hline 4 & Nam Đan & 6.2 & $\begin{array}{r}\text { Over alarm level 1 } \\
(0,8 \mathrm{~m})\end{array}$ & Medium & Medium & Similarity & High & No Similarity \\
\hline 5 & Chu Le & 16.56 & $\begin{array}{r}\text { Over alarm level 3 } \\
(3.06 \mathrm{~m})\end{array}$ & Very high & Very high & Similarity & High & No Similarity \\
\hline
\end{tabular}

(Data Source: Ha Tinh Committee for Flood and Storm Control)

* With the flood on October 15-16, 2013

- The flood hazard zoning map using six influence factors: Flood risk level in this map is suitable to the actual risk level at 5/6 hydrological stations, except Linh Cam station.

- The flood hazard zoning map using five influence factors: Flood risk level in this map is suitable to the actual risk level at two hydrological stations, Son Diem and Linh Cam.

Table 4. Water level, Alarm level and hazard level at Hydrological stations in flood event October 15-16, 2013

\begin{tabular}{|c|c|c|c|c|c|c|c|c|}
\hline No. & $\begin{array}{c}\text { Hydro } \\
\text { logical station }\end{array}$ & $\begin{array}{c}\text { Water level } \\
(\mathrm{m})\end{array}$ & Alarm level & $\begin{array}{c}\text { Hazard level in } \\
\text { reality }\end{array}$ & $\begin{array}{c}\text { Risk level on a } \\
\text { map using } \\
6 \text { factors }\end{array}$ & $\begin{array}{c}\text { Comparison } \\
\text { Results }\end{array}$ & $\begin{array}{c}\text { Risk level on a } \\
\text { map using } \\
5 \text { factors }\end{array}$ & $\begin{array}{c}\text { Comparison } \\
\text { Results }\end{array}$ \\
\hline 1 & Do Luong & 13.19 & $\begin{array}{c}\text { Under alarm level 1 } \\
(1.31 \mathrm{~m})\end{array}$ & Low & Similarity & Medium & No Similarity \\
\hline 2 & Son Diem & 14.62 & $\begin{array}{c}\text { Over alarm level } 3 \\
(1.62 \mathrm{~m})\end{array}$ & Very high & Very high & Similarity & Very high & Similarity \\
\hline 3 & Hoa Duyet & 11.26 & $\begin{array}{c}\text { Over alarm level } 3 \\
(0.76 \mathrm{~m})\end{array}$ & Very high & Very high & Similarity & High Similarity \\
\hline 5 & Linh Cam & 5.74 & $\begin{array}{c}\text { Over alarm level } 2 \\
(0.24 \mathrm{~m})\end{array}$ & High & Very high & No Similarity & High & Similarity \\
\hline 6 & Nam Đan & 6.5 & $\begin{array}{r}\text { Under alarm level 2 } \\
(0.4 \mathrm{~m})\end{array}$ & Medium & Medium & Similarity & No Similarity \\
\hline Chu Le & 14.42 & $\begin{array}{r}\text { Over alarm level 3 } \\
(0.92 \mathrm{~m})\end{array}$ & Very high & Very high & Similarity & High & No Similarity \\
\hline
\end{tabular}

(Data Source: Ha Tinh Committee for Flood and Storm Control)

* With the flood on October 15-16, 2016

- The flood hazard zoning map using six influence factors: Flood risk level in this map is suitable to the actual risk level at 4/6 hydrological stations, except Linh Cam and Son Diem station.

- The flood hazard zoning map using five influence factors: Flood risk level in this map is only suitable to the actual risk level at Linh Cam hydrological stations.

Table 5. Water level, Alarm level and hazard level at Hydrological stations in flood event October 15-16, 2016

\begin{tabular}{|c|c|c|c|c|c|c|c|c|}
\hline No. & $\begin{array}{l}\text { Hydrological } \\
\text { station }\end{array}$ & $\begin{array}{l}\text { Water level } \\
\text { (m) }\end{array}$ & Alarm level & $\begin{array}{l}\text { Hazard level in } \\
\text { reality }\end{array}$ & $\begin{array}{c}\text { Risk level on a } \\
\text { map using } \\
6 \text { factors }\end{array}$ & $\begin{array}{l}\text { Comparis-on } \\
\text { Results }\end{array}$ & $\begin{array}{c}\text { Risk level on a } \\
\text { map using } \\
5 \text { factors }\end{array}$ & $\begin{array}{l}\text { Comparis-on } \\
\text { Results }\end{array}$ \\
\hline 1 & Do Luong & 13.00 & $\begin{array}{c}\text { Under alarm level } 1 \\
(1.12 \mathrm{~m})\end{array}$ & Low & Low & Similarity & Medium & No Similarity \\
\hline 2 & Son Diem & 12.8 & $\begin{array}{c}\text { Below alarm level } 3 \\
(0.2 \mathrm{~m}) \\
\end{array}$ & High & Very high & No Similarity & Very high & No Similarity \\
\hline 3 & Hoa Duyet & 10.91 & $\begin{array}{c}\text { Over alarm level } 3 \\
(0.41 \mathrm{~m})\end{array}$ & Very high & Very high & Similarity & High & No Similarity \\
\hline 4 & Linh Cam & 5.5 & Alarm level 2 & High & Very high & No Similarity & High & Similarity \\
\hline 5 & Nam Đan & 5.66 & $\begin{array}{c}\text { Over alarm level } 1 \\
(0.26 \mathrm{~m})\end{array}$ & Medium & Medium & Similarity & High & No Similarity \\
\hline 6 & Chu Le & 15.64 & $\begin{array}{c}\text { Over alarm level } 3 \\
(2.14 \mathrm{~m})\end{array}$ & Very high & Very high & Similarity & High & No Similarity \\
\hline
\end{tabular}

(Data Source: Ha Tinh Committee for Flood and Storm Control) 
From the study results, it is observed that AHP provides a flexible, simple, step-by-step and transparent approach of analyzing complex problems in a multi criteria decision analysis (MCDA) environment based on experts and enduser preferences, knowledge, experience, and judgments. Further, the AHP- GIS based method to flood hazard assessment as utilized in this study is seen as a relatively inexpensive, easy to use, and more importantly, permits interactive implementation by flood managers for continuing improvement. Therefore, it was found that the changes in the set of criteria contributing to flood creation significantly affect the result of the hazard zoning map, and the changes were reasonable and acceptable. The results prove that adding the relative slope length parameter to calculate the model will increase the reliability of the research method. Also, the different results obtained from these two cases indicate the importance of the relative slope length factor in mapping flood hazard zoning.

These results also introduce a way to improve the accuracy of developing flood risk zoning map with AHP by adding a factor leading to the formation of floods when calculating the model. However, it is carefully considered to decide which factors can be supplemented and the matching capacity of these elements on the hierarchy and computation by the AHP algorithm. In addition, it is not recommended to add too many criteria, only a maximum of 9 criteria is sufficient because psychologists conclude that, nine objects are the most that an individual can simultaneously compare and consistently rank (Pawel 2010).

\section{CONCLUSION}

When studying flood hazard zoning by the AHP method, the criteria affecting the flood may change depending on data collection. However, besides using the common factors contribute to flooding in most terrain and geographic areas such as rainfall, slope, drainage density, land cover, and soil, it is advisable to add the relative slope length parameter as input data. This is the important criterion when studying the flood risk zoning for many basins in general and the Lam river basin in particular. This factor affects the volume of water, water accumulate ability, and flow velocity, thereby this contributes to flood risk. Results of flood hazard zoning using the relative slope length are more specific and accurate, thus accuracy and reliability of the warning work will be improved significantly. Especially for river basin with high flood frequency, areas with high elevations, high slope, and area with a long distance from the watershed line to the valley line, using the slope length in the flood risk study is necessary.

\section{REFERENCES}

Bagarello V. and Ferro V. (2010). Analysis of soil loss data from plots of differing length for the Sparacia experimental area, Sicily, Italy. Biosystems Engineering, [online]. 105(3), 411-422. Available at: www.sciencedirect.com/science/article/pii/S153751101000005X?via\%3Dihub [Accessed March 2010].

Bagio B., Bertol I., Wolschick H.N., Schneiders D., Santos M.A.D.N.D. (2017). Water Erosion in Different Slope Lengths on Bare Soil. Revista Brasileira de Ciência do Solo, [online]. 41. Available at: www.scielo.br/scielo.php?script=sci_arttext\&pid=\$0100-06832017000100505 [Accessed 09 March 2017].

Bastawesy M. El., White K. \& Nasr A. (2009). Integration of remote sensing and GIS for modelling flash floods in Wadi Hudain catchment, Egypt. Hydrological Processes, [online]. 23(9), 1359-1368, DOl: 10.1002/hyp.

Bhushan N. and Rai K. (2004). Strategic Decision Making: Applying the Analytic Hierarchy Process; Springer: London, UK.

Chau V.N., Holland J., Cassells S., Tuohy M. (2013). Using GIS to map impacts upon agriculture from extreme floods in Vietnam. Applled Geography. [online] 41, 65-74. Available at: www.sciencedirect.com/science/article/abs/pii/S0143622813000805 [Accessed July 2013].

Chinh L., Meding J. (2018). A Flood Risk Assessment of Quang Nam, Vietnam Using Spatial Multicriteria Decision Analysis. Water. [online] 10(4), 461. Available at: www.mdpi.com/2073-4441/10/4/461 [Accessed 8 April 2018].

Directorate for Roads of Vietnam, TCVN 9845:2013. (2013). Calculating of flood flow characteristics (in Vietnamese with English summary). Available at: www.vanbanphapluat.co/tcvn-9845-2013-tinh-toan-cac-dac-trung-dong-chay-lu [Accessed 20 May 2020].

Dung N.B., Minh D.T., Long N.Q., Ha L.T.T. (2020). Weights of factors contributing to flood formation in the Lam river basin, Vietnam, Journal of Southwest Jiaotong University, 55(2). Available at: www.researchgate.net/publication/341121252_WEIGHTS_OF_FACTORS_ CONTRIBUTING_TO_FLOOD_FORMATION_IN_THE_LAM_RIVER_BASIN_VIETNAM [Accessed April 2020].

El Alfy M. (2016). Assessing the impact of arid area urbanization on flash floods using GIS, remote sensing, and HEC-HMS rainfall-runoff modeling. Hydrology Research. [online] 47(6), 1142-1160, DOI: 10.2166/nh.2016.133.

Elkhrachy I. (2015). Flash Flood Hazard Mapping Using Satellite Images and GIS Tools: A case study of Najran City, Kingdom of Saudi Arabia ( KSA ). The Egyptian Journal of Remote Sensing and Space Sciences. [online] 18(2), 261-278, DOI: 10.1016/j.ejrs.2015.06.007.

Gilley J.E, Finkner S.C., Varvel G.E. (1987). Slope Length and Surface Residue Influences on Runoff and Erosion. Biological Systems Engineering: Papers and Publications, 148-152. Available at: www.digitalcommons.unl.edu/cgi/viewcontent.cgi?article=1120\&context=bios ysengfacpub [Accessed 20 May 2020].

Kandilioti G. and Makropoulos C. (2012). Preliminary flood risk assessment. The case of Athens. Natural Hazards. [online] 61(2), 441-468. Available at: www.link.springer.com/article/10.1007/s11069-011-9930-5 [Accessed 20 May 2020].

Kazakis N., Kougias I. \& Patsialis T. (2015). Science of the Total Environment Assessment of fl ood hazard areas at a regional scale using an index-based approach and Analytical Hierarchy Process : Application in Rhodope - Evros region, Greece. Science of the Total Environment. [online] 538, 555-563, DOI: 10.1016/j.scitotenv.2015.08.055.

Kinnell P.I.A. (2000). The Effect of Slope Length on Sediment Concentrations Associated with Side-Slope Erosion. Soil Science Society of America Journal. [online] 64, 1004-1008. Available at: www.researchgate.net/publication/235936764_The_Effect_of_Slope_Length_on_ Sediment_Concentrations_Associated_with_Side-Slope_Erosion [Accessed December 1999].

Kieu T.D. (2011). Research on large flood management in the Lam River basin, Ph.D. Thesis, Thuyloi University (in Vietnamese with English summary).

Lappas I. and Kallioras A. (2019). Flood Susceptibility Assessment through GIS-Based Multi-Criteria Approach and Analytical Hierarchy Process (AHP) in a River Basin in Central Greece. International Research Journal of Engineering and Technology (IRJET). [online] 6(3), 738-751. Available at: www.irjet.net/archives/V6/i3/IRJET-V613137.pdf [Accessed 3 March 2019].

Liu Q.Q. and Singh.V.P. (2004). Effect of Microtopography, Slope Length and Gradient, and Vegetative Cover on Overland Flow through Simulation. Journal of Hydrologic Engineering. [online] 9(5), 375-382, DOI: 10.1061/(ASCE)1084-0699(2004)9. 
Luu C., Von Meding J., Kanjanabootra S. (2018). Assessing flood hazard using flood marks and analytic hierarchy process approach: A case study for the 2013 flood event in Quang Nam, Vietnam. Natural Hazards. [online] 90, 1031-1050. Available at: www.researchgate. net/publication/320757449_Assessing_flood_hazard_using_flood_marks_and_analytic_hierarchy_process_approach_a_case_study_for_ the_2013_flood_event_in_Quang_Nam_Vietnam [Accessed November 2017].

Minh D.T. (2017a). Modeling methods and application for building a flood hazard zoning model. Journal of Mining and Earth Science, 58(4), 128-135 (in Vietnamese with English summary).

Minh D.T. (2017b). The application of GIS technology in establishing a land cover hierarchy map for zoning flood hazard in Lam river basin. Mining Industry Journal, 5, 37-40 (In Vietnamese with English summary).

Minh D.T. (2017c). The application of GIS technology to build a soil classification map following level of flood risk in Lam river basin. Journal of Science on Natural Resources and Environment, 16, 68-74 (in Vietnamese with English summary).

Minh D.T. (2019a). Application of GIS technology to establish a drainage density hierarchical map for flood hazard zoning in Lam river basin. Journal of Mining and Earth Sciences, 59(6), 32-42 (in Vietnamese with English summary).

Minh D.T. (2019b). Research on the application of special modeling in zoning flood hazard in flood warning in lam river basin, Ph.D. thesis, university of mining and geology (in Vietnamese with English summary).

Minh D.T and Dung N.B. (2017). Flood Hazard zoning in Lam river basin, Vietnam, using GIS and analytic hierarchy process (AHP). Proceedings of International Conference on Geo-Spatial Technologies and Earth Resources, 837-843.

Ministry of Science and Technology. (2009). Soil quality - Method for determination of soil erosion by rain. National Standards TCVN 5299: 2009, (in Vietnamese). Available at: www.vanbanphapluat.co/tcvn-5299-2009-chat-luong-dat-xac-dinh-muc-do-xoi-mon-dat-do-mua [Accessed 20 May 2020].

Myronidis D., Emmanouloudis D., Stathis D., Stefanidis P. (2009). Integrated flood hazard mapping in the framework of E.U directive on the assessment and management of flood risks. Fresenius Environ Bull. [online] 18(1), 102-111. Available at: www.researchgate.net/ publication/259451282_Integrated_flood_hazard_mapping_in_the_framework_of_the_EU_directive_on_the_assessment_and_ management_of_flood_risks [Accessed 20 May 2020].

Paweł C. (2010). Using the analytic hierarchy process in evaluating decision alternative. Operations research and decisions. [online] 1. Available at: www.researchgate.net/publication/227653945_Using_the_Analytic_Hierarchy_Process_in_Evaluating_Decision_Alternatives [Accessed 20 May 2020].

Phuong T.T., Minh P.T., Ngoc N.B. (2015). Application GIS and AHP to build the flood hazard zoning map in the Huong River basin, Thua Thien Hue province. Hue University Journal of Science. [online] Volume 13(112) (in Vietnamese). Available at: www.jos.hueuni.edu.vn/index. php/TCKHDHH/article/view/2232 [Accessed 20 May 2020].

Radwan F., Alazba A.A. \& Mossad, A. (2019). Flood risk assessment and mapping using AHP in arid and semiarid regions. Acta Geophysica, [online] 67(1), 215-229, DOI: 10.1007/s11600-018-0233-z.

Rahmati O., Zeinivand H. \& Besharat M. (2016). Flood hazard zoning in Yasooj region, Iran, using GIS and multi-criteria decision analysis. Geomatics, Natural Hazards and Risk. [online] 7(3), 1000-1017, DOI: 10.1080/19475705.2015.1045043.

Saaty T.L. (2012). Decision making in complex enviroments:The Analytic Network Process (ANP) for Dependence and Feedback. Pittsburgh. Available at: www.superdecisions.com/sd_resources/v28_man02.pdf [Accessed 20 May 2020].

Seejata K., Yodying A., Wongthadam T., Mahavik N. \& Tantanee S. (2018). Assessment of flood hazard areas using Analytical Hierarchy Process over the Lower Yom Basin, Sukhothai Province. Procedia Engineering. [online] 212, 340-347, DOI: 10.1016/j.proeng.2018.01.044.

Souissi D., Zouhri L., Hammami S., Msaddek M. H., Zghibi A. \& Dlala M. (2019). GIS-based MCDM-AHP modeling for flood susceptibility mapping of arid areas, southeastern Tunisia. Geocarto International. [online] 1-27, DOI: 10.1080/10106049.2019.1566405.

Tran P., Marincioni F., Shaw R., Sarti M., Van An L. (2008). Flood risk management in Central Vietnam: Challenges and potentials. Natural Hazards, 46(1), 119-138. Available at: www.link.springer.com/article/10.1007/s11069-007-9186-2

Tu L.H., Hong N.T., Liem N.D., Loi N.K. (2013). Integrating Analytic Hierarchy Process and GIS for Flood risk zoning in Vu Gia Watershed, Quang Nam Province, VNU Journal of Science. [online] 3(29), 64-72 (in Vietnamese with English summary). Available at: file:///Users/ad/Dow nloads/1110-1-2162-1-10-20160519\%20(1).pdf [Accessed 20 May 2020].

Vojtek M. \& Vojteková J. (2019). Flood susceptibility mapping on a national scale in Slovakia using the analytical hierarchy process. Water (Switzerland). [online] 11(2), DOI: 10.3390/w11020364.

Yongmei D., Xihuan S., Xianghong G., Shijun N. \& Juanjuan M. (2011). Analysis of Slope Length on Water Soil Erosion. International Conference on Consumer Electronics, Communications and Networks, CECNet. [online] 2943-2946, DOI: 10.1109/CECNET.2011.5769391.

Zhang H., Wei J., Yang Q., Baartman J.E.M., Gai L., Yang X., et al. (2017). An improved method for calculating slope length $(\lambda)$ and the LS parameters of the Revised Universal Soil Loss Equation for large watersheds. Geoderma. [online] 308, 36-45. Available at: www.sciencedirect. com/science/article/pii/S0016706116310059 [Accessed 15 December 2017].

Wischmeier W.H. and Smith D.D. (1978). Predicting rainfall erosion losses: a guide toconservation planning with Universal Soil Loss Equation (USLE) Agriculture Handbook, Department of Agriculture, Washington, DC. (703). Available at: www.naldc.nal.usda.gov/download/ CAT79706928/PDF [Accessed 20 May 202]. 